\title{
Consultation and informed opinion
}

One of the UK's leading papers reported on 19 October 2014 that the government would back the Medical Innovation Bill, the private Bill introduced by Lord Maurice Saatchi, at that time awaiting its committee stage in the House of Lords. ${ }^{1}$ Strikingly, earlier in the year the Department of Health had consulted on the Bill; it was opposed inter alia by the General Medical Council, the Academy of Medical Royal Colleges, the Wellcome Trust, the Medical Research Council, the Academy of Medical Sciences, the British Medical Association, the Medical Defence Union, the Medical Protection Society, the National Institute for Health and Care Excellence (NICE), several Royal Colleges individually, including the Royal College of Physicians, and heavyweight legal opinion from Sir Robert Francis and others. ${ }^{2}$

The Bill in its November 2014 form was awaiting the report stage in the House of Lords, prior to its third reading there, and being sent to the House of Commons (although, unusually in view of the rather vociferous committee stage, Lord Saatchi has agreed to a round-table discussion prior to the reporting stage). This Bill is refreshingly short - about 675 words. ${ }^{3}$ Its aim is to 'make provision about innovation in medical treatment'. (Robert Winston commented that a definition of innovation would be helpful, and offered one, but his amendment was not accepted. ${ }^{4}$ ) The Bill sets out to establish 'beyond doubt that it is not negligent for a doctor to depart from standard practice where he or she does so by applying an accountable and transparent procedure'; in simpler terms, it aims to prevent doctors being inhibited from trying out innovative unproven treatments. What can be so wrong about that?

Firstly, Lesley Turnberg, moving a number of amendments at the Lord's Committee stage, delicately commented that he feared he was not alone in wondering whether the Bill is necessary. ${ }^{4} \mathrm{He}$, allied with much medical opinion, believes that current legal tests provide adequate protection to doctors who wish to innovate. ${ }^{5}$ In this regard, perhaps most convincing is the fact that the two large UK medical defence organisations are explicit that they have no experience or evidence to suggest that doctors are deterred from innovating by the fear of litigation. ${ }^{2}$

While 'unnecessary' is one class of concern, 'undesirable' is another. Some legal advice argues that the well-tested (Bolan and Bolitho) criteria to gauge negligence and reasonableness of a doctor's actions would in fact be weakened by the Bill. ${ }^{2}$ On a less rarified and more mundane level, there are practical consequences that would be ushered in by this Bill. The Medical
Protection Society comments that patients may 'unrealistically expect this Bill to effectively authorise widespread introduction of innovative procedures of little real merit and it will be doctors that have to explain otherwise. ${ }^{5}$ Along the same lines but more forthrightly, the chief executive of the Patients Association is quoted as saying it was possible 'some gung-ho doctors will want to use dying patients as guinea pigs'. ${ }^{6}$ David Nicholl, a neurologist in Birmingham, has pointed out the potential of the Bill to allow charlatans to exploit vulnerable patients. ${ }^{7}$ One might anticipate that the 'accountable and transparent' preinnovation procedures ${ }^{3}$ defined by the Bill would prevent that, but the safeguards provided by that procedure seem weak. Thus, although the would-be innovator is required to seek the view of one or more appropriately qualified doctors in relation to the proposed treatment, he or she is only required to 'take full account of the views obtained' - this to a lay reader would seem to leave considerable wriggle room. An amendment proposing that these conversations should be recorded in the medical records was rejected at the committee stage in the House of Lords. ${ }^{4}$

On another hand, some commentators have pointed out the potential benefit to elements of the pharmaceutical industry, who may see a means of introducing new treatments while avoiding the rigours of properly organised clinical trials. ${ }^{8}$ Indeed, the Academy of Medical Royal Colleges among others highlight the potential short circuiting of the clinical trials procedure as one of its major objections. ${ }^{2}$ This is unlikely to be a merely theoretical concern. The newspaper article reporting the government backing for the Bill commended its value as 'cutting out the need for years of clinical trials...bring down the cost of the medicine...'

The debate over the last few months has and it must be hoped will continue to amend the Bill. A series of alterations suggested by Sir Bruce Keogh have changed some of the detail but not the main thrust. ${ }^{4}$ Although not enshrined in the Bill, the concern that the results of one-off innovative approaches might be lost has been addressed by an offer from Oxford University to set up a database containing anonymised information about those who agree to innovative treatments. ${ }^{9}$ While in principle this would seem appropriate, ensuring that this is kept up to date, accessible and searchable seems a major undertaking - requiring both funding and a means of policing that are currently unclear. Whatever the eventual fate of this Bill, its continued progress provides an interesting commentary on the Department of Health's consultative processes.

$\begin{array}{ll}\text { Members of the editorial board } \\ \text { Professor Humphrey Hodgson } & \text { Dr Cordelia Coltart } \\ \text { Editor } & \text { International editor } \\ \text { Dr Paul Grant } & \text { Cono Ariti } \\ \text { Editorial registrar } & \text { Statistical editor }\end{array}$

Dr Na'eem Ahmed

Paul Belcher

Dr Rodger Charlton

Dr Tahseen Chowdhury

Dr Kate Evans

Professor Brian Hurwitz
Dr Angela King Professor Martin McKee

Dr Roby Rakhit

Dr Ian Starke

Dr Kevin Stewart 


\section{References}

1 Hope C. Experimental drugs for patients could be available from March after Government backs Saatchi Bill. The Telegraph, 19 October 2014. Available online at www.telegraph.co.uk/health/ saatchi-bill/11173161/Experimental-drugs-for-patients-could-beavailable-from-March-after-Government-backs-Saatchi-Bill.html [Accessed 24 November 2014].

2 Anonymous. An overwhelming expert consensus against Saatchi Bill. Available online at http://dissentingdoc.wordpress.com/2014/05/01/ an-overwhelming-expert-consensus-against-saatchi-bill/ [Accessed 24 November 2014].

3 UK Government. Progress of the Medical Innovation Bill. Available online at http://services.parliament.uk/bills/2014-15/medicalinnovation.html [Accessed 24 November 2014].

4 UK Government. Lords Hansard text for 24 October 2014. Available online at www.publications.parliament.uk/pa/ld201415/ldhansrd/ text/141024-0001.htm [Accessed 24 November 2014].

5 Medical Protection Society. Medical Innovation Bill. Available online at www.medicalprotection.org/uk/casebook-september-2014/medical-innovation-bill [Accessed 24 November 2014].
6 Hope C and Donnelly L. Leading doctors join with cancer patients to back Lord Saatchi's Medical Innovation Bill. The Telegraph, 26 June 2014. Available online at www.telegraph.co.uk/health/saatchibill/10929131/Leading-doctors-join-with-cancer-patients-to-back-LordSaatchis-Medical-Innovation-Bill.html [Accessed 24 November 2014].

7 Nicholl D. Saatchi's 'Medical Innovation Bill' will benefit lawyers and charlatans, not patients. OurNHS, 22 October 2014. Available online at www.opendemocracy.net/ournhs/david-nicholl/ saatchi\%27s-\%27medical-innovation-bill\%27-will-benefit-lawyers-and-charlatans-not-pat [Accessed 24 November 2014].

8 Oborne $\mathrm{P}$ and Williams A. The 'Saatchi Bill' is dangerous and will bring nothing but harm. The Telegraph, 24 October 2014. Available online at www.telegraph.co.uk/health/saatchi-bill/11183012/TheSaatchi-Bill-is-dangerous-and-will-bring-nothing-but-harm.html [Accessed 24 November 2014].

9 Medical Innovation Bill. We are working with Oxford University on an innovation database. Available online at http://medicalinnovationbill. co.uk/we-are-working-with-oxford-university-on-an-innovationdatabase/.

Humphrey Hodgson 